\title{
Michaela Konrad, Emesa zwischen Klientelreich und Provinz. Identitätswandel einer lokalen Fürstendynastie im Spiegel der archäologischen Quellen (Orient-Archäologie - 34), Verlag Marie Leidorf GmbH, Rhaden/Wesft. 2014, pp. 108, ill. $\mathrm{b} / \mathrm{w}+$ tab. 7, ISBN 978-389646-664-8; ISSN 1434-162X
}

In the history of Rome, Emesa (now Homs) occupies a prominent place, and yet our knowledge of the history of this city remains extremely modest. Essentially it is limited to two periods. The first begins with the formation of contact between the rulers of Emesa, with Pompey, who was active in the East (64 BCE), and concludes with the city's incorporation into the Roman Empire in the 70s CE. Around the late second and third century $\mathrm{CE}$, for a brief period Emesa became an important political and religious centre. The marriage between Septimius Severus and Julia Domna, daughter of a priest of the god Elagabalus, who was venerated in the city, meant that not only during this emperor's rule, but also in that of his successors, Emesa enjoyed the favours of the rulers of Rome, a contributing factor to its rapid development. The small number of written sources makes it impossible to reconstruct not only the entire history of the city and its sanctuary, but even the architecture and topography of the sanctuary itself. Even the archaeological work that took place on the site of present-day Homs added little to our knowledge on this subject, as a result of its brief duration and limited scope.

Nevertheless, archaeologists do have access to certain data providing a picture of the cultural aspects of the rulers of Emesa in the final decades before it was incorporated into the Roman Empire. This data was provided by studies of the surviving examples of sepulchral architecture, and in particular the archaeological discoveries at the necropolis in Tall Abū Sābūn, near Homs, made in 1936. These excavations unearthed a number of graves, from which very precious artefacts were extracted. The exceptional nature of these finds suggests that the graves belonged to figures with a very high standing in the social hierarchy. For a long time, however, the results of the excavations remained generally unknown. The first extensive reports on them were published by Henri Seyrig only in 1952 and 1953. Owing to its artistic value and excellent condition, the greatest interest among the finds he described was attracted by a silver-plated helmet with a facemask. Until recently, there has been less interest in other types of discoveries, despite their uniqueness.

Only in recent years have the artefacts from the necropolis near Emesa come under the magnifying glass of Michaela Konrad. In her book, a long-time specialist in the archaeology of Syria, summarises and interprets the discoveries made there, as well as depicting the political-cultural context in which the rulers of Emesa operated.

The book is divided into six chapters, not including the introduction, of widely varying length. The first and shortest (Die Dynastie der Emeseni, p. 7) presents a concise history of the dynasty that ruled Emesa. In the second and longest (Die Nekropole von Emesa- 
Tall Abü Säbūn, pp. 9-45), Konrad describes the architecture and iconography of the imposing tomb of Samsigeramos, ruler of Emesa, which lay outside the boundaries of the necropolis. She compares it with other, similar well-known buildings in Syria (Hermel, Sirrin, Suweida), and describes in detail the finds made in the graves, which were studied in 1936 (graves no. 1, 6, 7-9, 10, 11, 14) (pp. 21-39) and Tab. 1 (pp. 79-84). On the basis of these finds, she also attempts to ascertain the time of specific burials (cf. pp. 39-41). According to the Author, the nature of the artefacts unearthed in grave no. 1 allow us to date it to the beginning of the first century $\mathrm{CE}$, and to assume that it belonged to a member of the ruling dynasty (pp. 40-41). The discoveries from graves no. 11 and 6 also show that here too were buried individuals connected to the ruling house (p. 41). Chapter 3 (Die Grabfunde von Emesa im Spiegel der Kultur- und Ereignisgeschichte Syriens um die Zeitenwende, pp. 43-45) consists of Konrad's interpretation of the artefacts found, which concludes that the majority were heavily influenced by Parthian-Iranian culture, and even Central Asian traditions. Only a few of them come from the Roman world. Their presence, particularly in grave no. 1, confirms that the deceased had close relations with the rulers of Rome. However, the similarity between the artefacts from the graves of the rulers of Emesa, who had close relations with the Roman world, with the inventory of the burials of local tribal leaders, means that we are justified in wondering about their cultural identity. This is the question that the Author endeavours to answer in the next two chapters (Die emesenischen Fürsten im Spannungsverhältnis zwischen Stammesautorität und ihrer Rolle als Klientelkönige Roms, pp. 47-58; Identität und Identitätswandel der emesenischen Fürsten im Spiegel der Ereignisgeschichte des 1. Jahrhunderts n. Chr., pp. 59-65).

As vassals of Rome, the rulers of Emesa were forced to both take care of their own interests and satisfy Roman expectations. In order to secure the favours of their suzerain, they had no choice but to adopt the models of conduct that were expected of them, but at the same time to nurture their native traditions. The policy of transformation of vassal states into provinces pursued by the Roman emperors during the first century CE, led to rapid changes in their social structure and the cultural identity of their elites. As the leadership of local elites was replaced with the structures of provincial administration, the elites became Romanised, abandoning their own customs and values systems. This process was also reflected in Emesa, with the tomb of Samsigeramos being a good example of the cultural changes to which it led.

We still know very little about not only Emesa, but also other minor vassal kings of Rome within Syria. Konrad's book can thus be regarded as a valuable contribution to our knowledge of this little-known world. This value is all the greater considering the fact that it makes use of archaeological materials which, though apparently known, have in fact never previously been interpreted satisfactorily. As a result, the picture of the political and cultural relations between Emesa and Rome that the Author paints adds new important details. In the final chapter, she answers the question about the factors that shaped these relations, how they were formed and what their effects were. Although it was an archaeologist that wrote this book, it can be highly recommended not only to specialists in this field, but to all scholars whose interests include the history and culture of Syria under Roman rule. 